\title{
Why is there a gender earnings gap in self-employment? A decomposition analysis with German data
}

\author{
Daniel SJ Lechmann and Claus Schnabel ${ }^{*}$
}

\author{
* Correspondence: \\ claus.schnabel@wiso.uni-erlangen.de \\ University of Erlangen-Nürnberg, \\ Chair of Labour and Regional \\ Economics, Lange Gasse 20, 90403, \\ Nürnberg, Germany
}

\begin{abstract}
Using a large data set for Germany, we show that both the raw and the unexplained gender earnings gap are higher in self-employment than in paid employment. Applying an Oaxaca-Blinder decomposition, about one quarter to one third of the difference in monthly self-employment earnings can be traced back to women working fewer hours than men whereas there are no robust segregation effects. Working time flexibility and career aspirations do not seem to contribute much to the gender earnings gap, whereas family background plays a certain role as it affects the earnings of self-employed men and women quite differently.
\end{abstract}

JEL codes: J31, J71

Keywords: Earnings differential, Gender pay gap, Germany, Self-employment

\section{Introduction}

It is well-known that women earn less than men in paid employment. The public often perceives this difference in wages as discrimination against women, and policy makers give high priority to overcoming this inequality (see e.g. European Commission 2011). Economic and sociological research, however, has shown that the difference in wages can largely be traced back to women having different productive characteristics than men (in particular different human capital endowments), choosing different occupations and working fewer hours (see Altonji and Blank 1999 for a survey and Weichselbaumer and Winter-Ebmer 2005 for a meta-analysis of this strand of literature). Yet even when accounting for these differences, a substantial part of the gender pay gap cannot be explained and is then usually assumed to reflect employer discrimination against women.

One possibility to ensure not being discriminated by one's employer evidently is being one's own employer, i.e. becoming self-employed. Hence, if employer discrimination played a major role, the gender gap in self-employment earnings could be expected to be significantly lower than the gender wage gap in paid employment (Moore 1983). There is some empirical evidence, however, suggesting that exactly the opposite is the case - both raw and unexplained gender earnings gaps seem to be higher in self-employment than in paid employment (see, e.g., Eastough and Miller 2004, Álvarez et al. 2009). This is somewhat puzzling, in particular as other potential sources of discrimination such as discriminating behavior of customers or capital providers do not seem to play a substantial role for self-employed women. While it is true

(c) 2012 Lechmann and Schnabel; licensee Springer. This is an Open Access article distributed under the terms of the Creative Commons Attribution License (http://creativecommons.org/licenses/by/2.0), which permits unrestricted use, distribution, and reproduction in any medium, provided the original work is properly cited. 
that women generally start self-employment with less start-up capital than men and that financial constraints seem to contribute to the gender earnings gap to some extent (e.g. Hundley 2001, Walker 2009, Rybczynski 2009), there is no conclusive evidence whether this is due to discrimination by capital lenders (see, inter alia, Asiedu et al. 2012, Orser et al. 2006, Verheul and Thurik 2001, Coleman 2000, Fabowale et al. 1995). Also discrimination by consumers does not seem to explain the self-employment gender earnings gap (see Aronson 1991: 72-73, Moore 1983).

Even though there exists a large gender gap in self-employment earnings for which discrimination does not provide a satisfactory explanation, relatively few studies have attempted to explore the causes of this gap (e.g. Hundley 2001 and Walker 2009 for the U.S., Eastough and Miller 2004 for Australia and the U.S., Leung 2006 for Canada, Álvarez et al. 2009 for Spain and Tansel 2000 for Turkey) ${ }^{1}$. While the analyses by Hundley (2001) and Walker (2009) with U.S. data point to the relevance of working hours and household production as an important factor for explaining gender earnings differences, the effects of these variables are not always robust to selecting men or women as the reference group. Other studies, not considering hours and housework, mostly find the segregation of men and women into different industries or occupations to be among the most important contributions to the gender earnings gap. The percentage of the earnings gap that can be explained by endowment differences between men and women varies widely from practically zero percent (Álvarez et al. 2009, Tansel 2000) up to almost 100 percent (Leung 2006).

When it comes to Germany, the empirical evidence is especially scarce. In an early study, Jungbauer-Gans (1999) examines the earnings gap in 1995 using the German Micro Census which, however, only provides earnings data in intervals. For the selfemployed, she finds a small earnings gap which becomes larger but insignificant when attempting to correct for selection into (self-)employment, and does not perform a decomposition analysis. A recent survey by Gather et al. (2010) provides some bivariate inspection of the gender earnings gap in Germany. Based on the 2007 wave of the German Socio-Economic Panel (GSOEP) the authors calculate that fulltime selfemployed women earn 34.7 percent less than men in self-employment. Observing that, when analyzed on their own, neither human capital nor segregation into industries nor the existence of children can explain the earnings gap, they conclude that multivariate decomposition analysis is needed to identify the determinants of earnings differences (and the unexplained residual) for the self-employed.

Our study attempts to fill this gap in the literature by identifying and decomposing the causes of the self-employment gender earnings gap in Germany, using the gender pay gap in paid employment as a benchmark. Utilizing a rich cross-sectional dataset with continuous information on earnings (rather than earnings intervals), we analyze whether the raw and the unexplained gender earnings gap differ between self-employment and paid employment. Our dataset provides, among others, detailed information on human capital endowments of individuals, on personal characteristics including career aspirations, on job characteristics such as working hours, working time flexibility, professional field and task profile, and on firm size. This enables us to test whether self-employed women earn less than men because they differ in productivity-related attributes or own different types of businesses. We are also able to analyze whether it is different motivations and nonmonetary aspects that contribute to the gender earnings gap, i.e. whether self-employed 
women earn less because they are seeking work-family balance rather than profits. That said, a limitation of this rich data set is that it is only cross-sectional, so that unobserved heterogeneity can hardly be taken into account. Yet we will perform a Heckman (1979) selection correction as a robustness check in order to address the issue of selection on unobservables into self-employment or paid employment.

In order to explain the gender earnings gap one has to identify variables that differ between male and female self-employed and at the same time affect earnings in such a way that they may account for the lower female earnings. Accordingly this paper is structured as follows: In section 2, after presenting our data, we describe men's and women's distribution of earnings and their differences in endowments, motivations and job characteristics that may be responsible for the gender earnings gap. We then explore the impact of these variables by estimating earnings functions in section 3. Section 4 decomposes the gender earnings gap utilizing an Oaxaca-Blinder-decomposition, and section 5 concludes.

\section{Data and descriptive evidence}

The representative data set used in this study is the BIBB/BAuA Employment Survey of the Working Population on Qualification and Working Conditions in Germany 2006 (Hall and Tiemann 2006; for a detailed description see Zopf and Tiemann 2010). The data contains information on 20,000 individuals from the German active labor force population (excluding apprentices) who are at least 15 years old and regularly work at least 10 hours per week. The group of self-employed individuals consists of tradesmen and liberal professionals (coded as "Selbständige" and "freiberuflich Tätige" in the data set), but we exclude helping family members and freelance collaborators from our analysis since they are neither typical self-employed nor employees. As paid employees we have white-collar workers, blue-collar workers and civil servants. Observations with weekly working time of 100 hours or more are dropped for plausibility reasons. Additionally we remove self-employed and paid employees reporting earnings in the bottom 1 percent quantile of their respective earnings distribution to exclude some extremely low values. For the self-employed this means that we lose 13 observations, 9 of which report gross monthly earnings of just $€ 1$. Regarding the group of employees, 120 observations with gross monthly wages of $€ 200$ and less are eliminated ${ }^{2}$. Our sample then consists of 15,452 individuals who report income data and have no missing covariates. These include 974 male and 497 female self-employed individuals and 7,094 male and 6,887 female paid employees. It is clear from these figures that men select into self-employment much more often than women. The self-employment share among men amounts to 13.7 percent, whereas it is just about half as high among women, amounting to 7.2 percent.

Table 1 displays the distribution of earnings among men and women in paid and selfemployment in our sample. Before discussing the respective figures it should be noted that that for several reasons it is not advisable to compare the absolute levels of earnings between the two occupational groups (cf. Parker 2009: chs. 13.1, 13.2): Data on selfemployment earnings usually suffer from under-reporting and large non-response rates, and they often comprise not only labor but also capital income and not only money drawn from the business but also retained profits. As to our data, the self-employed were explicitly asked not to report their business profits or turnover but their earnings (whereas paid employees were asked to report their wages). Thus the measure of self-employment 
Table 1 Distribution of earnings among men and women in self- and paid employment ${ }^{a}$

\begin{tabular}{|c|c|c|c|c|c|c|}
\hline & \multicolumn{3}{|c|}{ Self-employed } & \multicolumn{3}{|c|}{ Paid Employees } \\
\hline & male & female & difference (in \%) & male & female & difference (in \%) \\
\hline \multicolumn{7}{|c|}{ Gross monthly earnings (in €) } \\
\hline Mean & 4,178 & 2,329 & -44.2 & 3,176 & 2.022 & -36.3 \\
\hline 25th percentile & 2,000 & 800 & -60.0 & 2,100 & 1,200 & -42.9 \\
\hline Median & 3,000 & 1,700 & -43.3 & 2,800 & 1,900 & -32.1 \\
\hline 75th percentile & 5,000 & 3,000 & -40.0 & 3,800 & 2,682 & -29.4 \\
\hline \multicolumn{7}{|l|}{ Hourly earnings (in €) } \\
\hline Mean & 21.5 & 15.3 & -28.8 & 17.1 & 13.8 & -19.4 \\
\hline 25th percentile & 10.0 & 6.2 & -37.8 & 11.6 & 9.3 & -20.0 \\
\hline Median & 15.5 & 10.9 & -30.0 & 15.5 & 12.8 & -17.5 \\
\hline 75th percentile & 23.3 & 18.6 & -20.0 & 20.3 & 17.0 & -16.4 \\
\hline No. of observations & 974 & 497 & & 7,094 & 6,887 & \\
\hline
\end{tabular}

earnings in the present study likely corresponds best to draw, the money drawn from the business on a regular basis by the owner (cf. Parker 2009: 363). The precise measurement of earnings and the definitions of our explanatory variables are provided in Table 2.

Returning to Table 1 and starting with the self-employed, gross monthly earnings of men in self-employment are on average $€ 4,178$, while self-employed women earn only $€ 2,329$ on average. Calculating the difference and taking men as the reference group yields a gender earnings gap of 44.2 percent in self-employment. A look at the quartiles of the earnings distribution reveals that women often have relatively low earnings and that the gender earnings gap is particularly pronounced in the lower part of the distribution. 25 percent of the women in self-employment report earnings that are not higher than $€ 800$ per month. In contrast, the lowest quartile of the male earnings distribution amounts to $€ 2,000$ - a differential of 60 percent. The income difference between the sexes is clearly smaller when it comes to hourly earnings, reflecting the fact that self-employed women work fewer hours than men. The earnings gap is now 28.8 percent on average, and it is again largest at the 25th percentile. Unsurprisingly, women also earn less than men in paid employment. Male employees' monthly gross wages average $€ 3,176$ whereas women only earn $€ 2,022$ on average, which makes a difference of 36.3 percent. The same is true for hourly earnings, where the gender pay gap amounts to 19.4 percent. Comparing the various differentials makes clear that the gender earnings gap is larger in self-employment than in paid employment ${ }^{3}$.

Several variables that may be responsible for the lower earnings of female self-employed have been identified in the literature (see the reviews by Parker 2009: 191-194 and Minniti 2009: chs. 9, 11). These may be grouped into three categories: (1) human capital, (2) work-family balance and working hours, and (3) segregation, which can be investigated with our data ${ }^{4}$.

\section{(1) Human capital}

Human capital seems to be one major determinant of self-employment earnings (see Parker 2009: ch. 13.6 and the literature cited therein). Therefore, analogous to wage differences in paid employment, women in self-employment should earn less than men if they 
Table 2 Measurement of independent and explanatory variables ${ }^{a}$

\begin{tabular}{|c|c|}
\hline Earnings & $\begin{array}{l}\text { The exact questions asked were: For self-employed: "Now to your monthly gross } \\
\text { earnings. We do not mean your monthly turnover or profit. Do not include child } \\
\text { allowance, please. What are your monthly gross earnings from your work as }<\text { job of } \\
\text { interviewee }>\text { ?" For paid employees: "Now to your monthly gross earnings, i.e. your } \\
\text { wage before taxes and social security contributions. Do not include child allowance, } \\
\text { please. What are your monthly gross earnings from your work as }<\text { job of } \\
\text { interviewee }>\text { ?" }\end{array}$ \\
\hline Formal education & $\begin{array}{l}6 \text { dummies: no vocational degree (reference), no vocational degree but FHR } \\
\text { ("Fachhochschulreife") or "Abitur", vocational training ("Berufsausbildung"), vocational } \\
\text { training and FHR or "Abitur", vocational college "“Fachschule"), university degree or } \\
\text { university of applied science ("Fachhochschule"). "Abitur" is the German university } \\
\text { entrance qualification, "Fachhochschulreife" the German university of applied } \\
\text { science entrance qualification. }\end{array}$ \\
\hline Working experience & Years since having been employed for the first time. \\
\hline Working intermissions & $\begin{array}{l}\text { Total number of years of working intermissions. As intermissions considered are: } \\
\text { unemployment, parental leave, military/civilian service, voluntary social year, times of } \\
\text { vocational training. Not counted as intermissions are: times of further education, } \\
\text { paid maternity leave, times of sickness. }\end{array}$ \\
\hline Tenure at current job & $\begin{array}{l}\text { Self-employed: Years running the current business. Paid employees: Years working at } \\
\text { the current workplace. }\end{array}$ \\
\hline $\begin{array}{l}\text { Number of changes of } \\
\text { profession }\end{array}$ & $\begin{array}{l}\text { The exact question asked was: "Taking all jobs together: How many different } \\
\text { professions, i.e. professions that differ fundamentally with respect to the kind of } \\
\text { work, have you been performing since your first job in the year < year when first } \\
\text { being employed }>\text { ?" }\end{array}$ \\
\hline Working hours & $\begin{array}{l}\text { Average usual weekly working hours including overtime, on-call duty, etc. If no } \\
\text { answer to usual weekly working time was provided this variable contains last week's } \\
\text { actual working hours. }\end{array}$ \\
\hline Working time flexibility & $\begin{array}{l}\text { The exact question asked was: "Are you able to take family and private interests into } \\
\text { account at your working time scheduling?" Possible answers: often, sometimes, } \\
\text { never. } 3 \text { dummies, reference: never. }\end{array}$ \\
\hline Life partner & $\begin{array}{l}\text { If interviewee was married he/she was asked whether he/she lived together with } \\
\text { his/her spouse. If interviewee was not married or did not live together with his/her } \\
\text { spouse he/she was asked whether he/she lived together with a partner. } \\
\text { Dummy } 1 \text { indicates that interviewee lives together with a spouse/partner. }\end{array}$ \\
\hline Young children & Dummy indicating whether children aged $0-5$ live in the household. \\
\hline High career aspirations & $\begin{array}{l}\text { The exact question asked was: "How important is it for you to get ahead at work, } \\
\text { resp. to make a career?" Possible answers: essential, very important, fairly important, } \\
\text { not very important, not at all important. Dummy: } 1 \text { = essential/very important/fairly } \\
\text { important, } 0=\text { not very important/not at all important. }\end{array}$ \\
\hline Tasks occurring at work & $\begin{array}{l}\text { For } 17 \text { groups of tasks (e.g. "nursing, parenting, healing", "monitoring and governing } \\
\text { machines, facilities or technical processes") it was asked whether that task occurred } \\
\text { at work sometimes, often or never. } 17 \text { dummies: } 1=\text { often/sometimes, } 0=\text { never. }\end{array}$ \\
\hline Firm size & $\begin{array}{l}8 \text { dummies: 1, 2, 3-4, 5-9 (reference), 10-19, 20-49, 50-99, } 100 \text { and more } \\
\text { employees. The number of employees includes the owner of the firm. }\end{array}$ \\
\hline Professional field & $\begin{array}{l}54 \text { dummies according to the classification of professional fields of the Federal } \\
\text { Institute of Vocational Education and Training, Bonn (see Tiemann et al. 2008). }\end{array}$ \\
\hline
\end{tabular}

possess less human capital. Table 3 shows that in Germany women still have lower levels of formal education on average. While the shares of men and women with a university degree are almost equal among the self-employed, only 3 percent of female (but 14 percent of male) self-employed have attended vocational college, and women are over-represented among those self-employed with only vocational training or no vocational degree at all. A similar gender difference shows up among paid employees (who in general have lower levels of education than the self-employed): Women do have a university degree nearly as often as men, but they still have less education on average. The difference in educational levels, however, seems to be less pronounced for paid employees which could be one explanation for the larger gender earnings gap in self-employment ${ }^{5}$. 
Table 3 Descriptive statistics on the characteristics of self-employed and paid employees $^{a}$

\begin{tabular}{|c|c|c|c|c|}
\hline & \multicolumn{2}{|c|}{ Self-employed } & \multicolumn{2}{|c|}{ Paid employees } \\
\hline & male & female & male & female \\
\hline No vocational degree (dummy) & 0.02 & 0.05 & 0.04 & 0.06 \\
\hline No vocational degree \& FHR/Abitur (dummy) & 0.04 & 0.04 & 0.03 & 0.02 \\
\hline Vocational training (dummy) & 0.26 & 0.30 & 0.48 & 0.51 \\
\hline Vocational training \& FHR/Abitur (dummy) & 0.11 & 0.14 & 0.08 & 0.12 \\
\hline Vocational college ("Fachschule") (dummy) & 0.14 & 0.03 & 0.09 & 0.04 \\
\hline University or university of applied science degree (dummy) & 0.44 & 0.43 & 0.28 & 0.25 \\
\hline Working experience (in years) & $22.9(11.9)$ & $21.2(11.0)$ & $20.1(10.8)$ & $20.2(11.1)$ \\
\hline Working intermissions (in years) & $0.93(1.94)$ & $2.83(4.31)$ & $0.96(1.88)$ & $2.59(4.02)$ \\
\hline Tenure at current job (in years) & $10.2(9.1)$ & $7.9(8.1)$ & $8.6(8.0)$ & $7.9(7.5)$ \\
\hline Number of changes of profession & $2.08(1.98)$ & $2.09(1.63)$ & $1.91(1.77)$ & $1.64(1.56)$ \\
\hline Working hours per week & $49.4(15.9)$ & $37.1(17.1)$ & $43.2(9.2)$ & $33.6(11.8)$ \\
\hline Working time flexibility: never (dummy) & 0.09 & 0.05 & 0.07 & 0.06 \\
\hline Working time flexibility: sometimes (dummy) & 0.41 & 0.30 & 0.34 & 0.29 \\
\hline Working time flexibility: often (dummy) & 0.50 & 0.65 & 0.59 & 0.66 \\
\hline Life partner (dummy) & 0.71 & 0.63 & 0.66 & 0.61 \\
\hline Young children (dummy) & 0.14 & 0.14 & 0.16 & 0.12 \\
\hline High career aspirations (dummy) & 0.54 & 0.58 & 0.58 & 0.47 \\
\hline Number of tasks occurring at work & $9.80(3.11)$ & $9.17(3.22)$ & $8.79(3.03)$ & $8.12(3.50)$ \\
\hline Firm size: 1 employee (dummy) & 0.44 & 0.57 & 0.003 & 0.004 \\
\hline Firm size: 2 employees (dummy) & 0.12 & 0.11 & 0.01 & 0.01 \\
\hline Firm size: 3-4 employees (dummy) & 0.16 & 0.10 & 0.02 & 0.05 \\
\hline Firm size: 5-9 employees (dummy) & 0.14 & 0.09 & 0.06 & 0.12 \\
\hline Firm size: 10-19 employees (dummy) & 0.07 & 0.06 & 0.09 & 0.13 \\
\hline Firm size: 20-49 employees (dummy) & 0.04 & 0.04 & 0.16 & 0.18 \\
\hline Firm size: 50-99 employees (dummy) & 0.01 & 0.01 & 0.13 & 0.13 \\
\hline Firm size: 100 employees and more (dummy) & 0.02 & 0.03 & 0.53 & 0.38 \\
\hline
\end{tabular}

${ }^{a}$ The data set used is the BIBB/BAuA Employment Survey 2006. Std. dev. in brackets (except for dummy variables). "Abitur" is the German university entrance qualification, "FHR" ("Fachhochschulreife") the German university of applied science entrance qualification. Working time flexibility was measured by the frequency at which interviewees were able to take family and private interests into account when scheduling working time. The number of employees reported in the firm size variable includes the owner of the firm.

Turning to working experience (measured as years since first holding a job), women have slightly less working experience than men in self-employment (21.2 vs. 22.9 years) and they record longer working intermissions. The working intermissions of selfemployed men sum up to 0.93 years whereas those of women amount to 2.83 years on average. While this difference between the sexes also exists in paid employment, it is again more pronounced among the self-employed. Additionally self-employed women have less specific working experience, as indicated by a lower tenure at the current job. While men run their current businesses for 10.2 years on average, women run theirs only for 7.9 years. In paid employment the gender difference is much smaller. Taken together, these findings may explain why there is a gender earnings gap and why it is larger in self-employment. 
Lazear (2004) points out that for entrepreneurs not only the level but also the diversity of human capital might be relevant, with more diversity inducing more income. Entrepreneurs thus should be jacks-of-all-trades (i.e. generalists) in order to be able to manage their businesses, but employees should specialize in certain tasks. If men have a more diverse professional background than women, this could explain why they earn more in self-employment. Moreover, it could also explain why the gender earnings gap is larger in self-employment, since this diversity would not benefit men in paid employment. Table 3 shows indeed that the self-employed have a more diverse background (measured as the number of changes of profession) than paid employees. However, self-employed women do not report fewer changes of profession than self-employed men, suggesting that diversity of human capital will not contribute to explaining the gender earnings gap.

\section{(2) Work-family balance and working hours}

There are some indications that women choose self-employment in order to obtain more flexibility and to better balance work and family (e.g. Boden 1999, Lombard 2001; for a survey see Gerlach and Damhus 2010). At the same time it is plausible that the more hours and effort women spend for family and housework responsibilities, the less hours and energy they are able to spend working in their firm, hence earning less money than men whose work efforts are less confined by housework and family engagements (Becker 1985, Hundley 2000, 2001, Walker 2009) ${ }^{6}$. Indeed our data in Table 3 show that women's working hours per week (referring to market work only) are quite below that of men, in self-employment as well as in paid employment. Selfemployed men work as much as 49.4 hours per week on average, women in self-employment just 37.1 hours. Interestingly, women in self-employment work more hours than women in paid employment, whose average weekly working time amounts to 33.6 hours, which contradicts the view that women choose self-employment in order to have more time for other activities. In contrast to this view, self-employment may enable women to spend more time on market work as would otherwise be possible. For instance, being their own boss, they can more easily work odd hours such as nights or weekends. However, self-employed women (as well as self-employed men) do not seem to be able to better balance working time scheduling with family and private interests than women (respectively men) in paid employment. For instance, 66 percent of female employees and 65 percent of female self-employed state that they often succeed in taking family and private interests into account when scheduling their working time. Still self-employed women's working time scheduling is far more flexible than men's. Only 50 percent of men in self-employment often succeed in balancing work and life (and 9 percent never do). This could indicate a trade-off between earnings and working time flexibility in self-employment where men and women locate at different combinations.

Being asked about their attitude towards career advancement self-employed women significantly more often stated high career aspirations than women in paid employment, namely 58 percent vs. 47 percent (which is even higher than the share of 54 percent of male self-employed stating high career aspirations). This may indicate that women with high career aspirations choose self-employment because paid employment does not provide them with satisfactory career opportunities (e.g., because of the existence of a "glass ceiling"), whereas women who attach less importance to career advancement (and 
more to family-work balance) stay in paid employment. Looking at family background, we find no substantial differences in terms of living with a partner and presence of young children (aged 0-5) in the household between self-employed women and women in paid employment.

Altogether these descriptive findings do not suggest that women choose selfemployment primarily as a means of providing more time and energy to family and housework. That said, women clearly work less hours in self-employment than men and their working time scheduling is far more flexible. This may well explain why they earn less in self-employment, but it does not necessarily explain why the gender earnings gap is higher in self-employment.

\section{(3) Segregation}

Women tend to concentrate in industries with high competition and low growth and income prospects (Minniti 2009: 568; on self-employed women's sector distribution in Germany see Lauxen-Ulbrich and Leicht 2005: chs. 5.5, 6.3). In our data set we have information on 54 professional fields individuals work in (regarding the classification of the professional fields see Tiemann et al. 2008). In order to provide an intuition on the segregation of self-employed women and men in different fields and for the sake of clarity Figure 1 only displays the three professional fields where most self-employed men and the three fields where most self-employed women are active in. It can be seen that a large share of self-employed men, namely 13.9 percent, are active in management, management consultancy and accounting, whereas the share of female selfemployed in this field is only 8.5 percent. Many self-employed men also work as engineers and in mercantile professions without retail, wholesale and credit business (e.g. agent middlemen, real estate agents), where self-employed women are found less often. In contrast, women in self-employment are mainly active in social professions, as teachers (e.g. music teachers), and in healthcare professions without licensure where the share of self-employed men is considerably lower. But women not only segregate into other professional fields, their businesses also are different from men's in terms of size (cf. Lauxen-Ulbrich and Leicht 2005: chs. 5.6, 6.7). As can be seen from Table 3, the majority of self-employed women, namely 57 percent, are so-called solo-self-employed, i.e. they do not have any other employees. This is only the case for 44 percent of selfemployed men.

The sectoral segregation of the sexes is also mirrored by the tasks they perform. We have information on 17 tasks that may occur at the work of individuals. Taking nursing, parenting, healing as an example, this task is occurring at the work of 34 percent of female self-employed but is only relevant for 21 percent of self-employed men. Monitoring and governing machines, facilities or technical processes is being performed by 41 percent of male and only 24 percent of female self-employed. Remarkably women not only perform different tasks but they also face fewer different tasks at their work than men, with self-employed men performing 9.80 and self-employed women performing 9.17 tasks on average (see Table 3). A similar difference shows up for paid employees ${ }^{7}$.

We expect that all these facts contribute to the explanation of the gender earnings gap. We cannot say a priori, however, whether segregation should play a more important role in self- or in paid employment. 


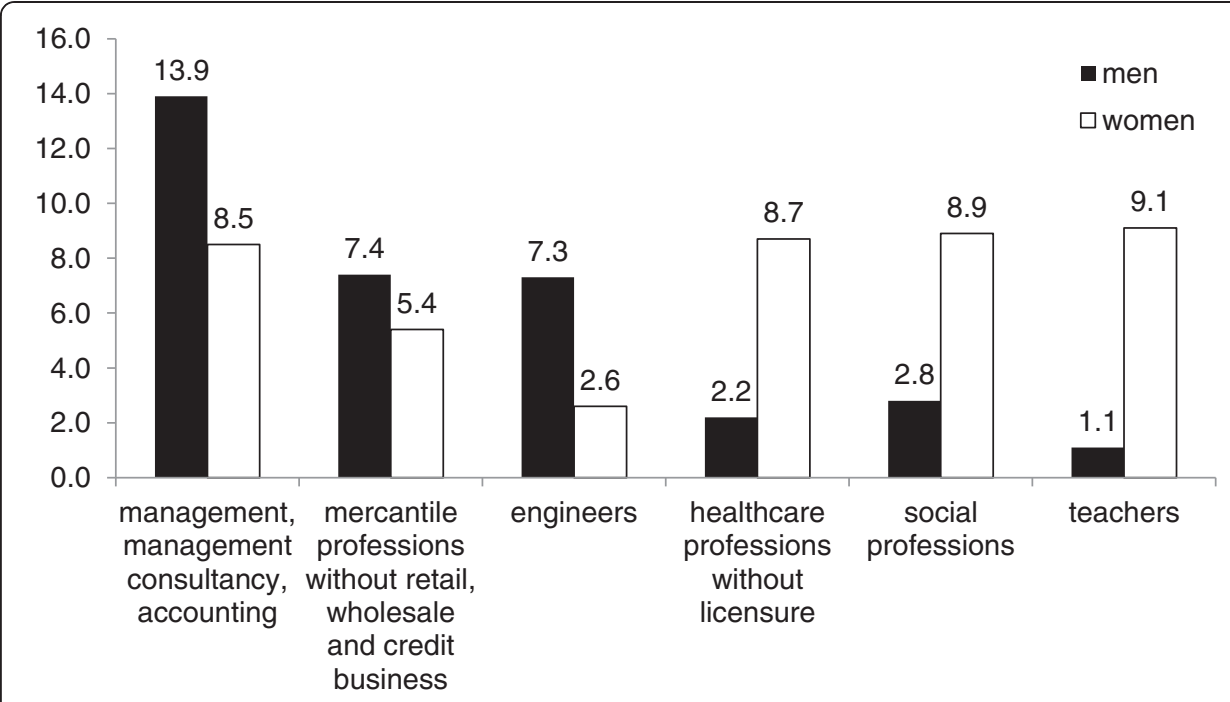

Figure 1 Share of self-employed men and women working in certain professional fields (in percent). The data set used is the BIBB/BAuA Employment Survey 2006. The figure displays those three out of 54 professional fields where most self-employed men are active in and those three professional fields where most self-employed women are active in.

\section{Determinants of self-employment earnings}

We now turn to exploring how the variables discussed above are related to earnings, and whether there are important differences between self-employment and paid employment. This is investigated by estimating various earnings regressions that either include a sex dummy or are run separately for men and women. As the dependent variable we use the logarithm of monthly earnings rather than hourly earnings as is usually done in wage regressions of paid employees, because we want to see to what extent gender earnings differences can be traced back to women working fewer hours, and whether this effect differs between paid employment and self-employment. Our explanatory variables, which were already discussed in section 2 , are the following: Human capital is captured by 6 dummies for educational degrees, the years of working experience, working intermissions and tenure (all in linear and quadratic form), and the number of changes of profession. The amount and the flexibility of working time are captured by (the logarithm of) weekly working hours and by the frequency at which individuals succeeded in balancing working time scheduling with family and private interests (3 dummies). We use a dummy for living together with a partner and a dummy for the existence of young children (aged 0-5) in the household to reflect family background. We also include the interaction of these two dummies, thus differentiating between individuals with partner and young children, individuals with partner and no young children, singles with young children and singles without young children (who form the reference group). Furthermore a dummy variable indicating high career aspirations is included. 54 dummies for different professional fields, 17 dummies for the tasks occurring at work and 8 firm size dummies serve as segregation variables. Finally, we include some control variables such as migration background, disability status and place of residence.

The regression results in Table 4 (column 1) show that the raw gender earnings gap in self-employment amounts to $72.0 \log$ points $^{8}$. When we include all explanatory and 
control variables (column 2) it decreases to 33.2 log points, which still is a substantial amount and is statistically significantly different from zero at the 1 percent level. In particular this is more than twice as high as the gender wage gap of 12.6 log points which we obtain in the multivariate wage regression for paid employees (column 4). Thus our finding from the descriptive analysis in section 2 that the gender earnings gap in self-employment is larger than in paid employment still holds and is even strengthened when comparing individuals with similar jobs and personal characteristics.

In order to examine the impacts and the differences of determinants of earnings the sexes, we now look at separate earnings regressions for men and women. The estimates of these regressions for self-employed and paid employees can be found in Table 5, and we will discuss the results in the same order as in section 2 .

\section{(1) Human capital}

While women on average have less formal education than men, as reported in section 2 , this does not appear to matter in self-employment. The estimated coefficients of the education dummies do not indicate a clear relationship between earnings and education for self-employed men, but tend to go in the expected direction (and are relatively large) for self-employed women. However, none of the education dummies is statistically significant in the self-employment earnings regressions of either men or women, and they are jointly significant at the 10 percent level only for women. This is in line with Williams (2003) who also found education to be insignificant for self-employment earnings in Germany, even when attempting to control for education endogeneity and self-selection bias. Quite in contrast, looking at the respective estimates for paid employees shows the expected pattern. The wage generally rises with the level of formal education and formal education is jointly statistically significant at the 0.1 percent level for both sexes. In addition, men benefit more from education than women. Formal education hence clearly seems to explain earnings differences in paid employment but the same does not apply to self-employment.

Working experience also is neither significant for self-employed men nor selfemployed women. Working intermissions only seem to be relevant for self-employed men's earnings, where having one additional year of working intermissions is linked to about $4.7 \log$ points less income 9 . For self-employed women intermissions do not appear to be significant, neither in statistical nor in economic terms. Taken together, lower general working experience should not harm women's earnings in self-employment. In paid employment, however, we have the usual results in that working experience and working intermissions have the expected signs and are statistically significant at least at the 1 percent level for both men and women. A limitation of our data is that we do not know to what extent working experience was acquired while working in paid employment or self-employment. One reason for the seemingly low relevance of general working experience for self-employment earnings could be that the self-employed in large part gathered experience as paid employees in the past and that this occupation-specific experience may not have any significant payoff in self-employment ${ }^{10}$. It might thus be more promising to look at specific working experience in self-employment.

Indeed, the crucial human capital variable for earnings in self-employment seems to be specific working experience measured as tenure at the current job, i.e. how long individuals have been running their current businesses. For men one additional year of tenure 
Table 4 OLS monthly earnings regressions, men and women pooled ${ }^{\mathrm{a}}$

\begin{tabular}{|c|c|c|c|c|}
\hline \multirow{2}{*}{$\begin{array}{l}\text { dependent variable: logarithm of gross } \\
\text { monthly earnings }\end{array}$} & \multicolumn{2}{|c|}{ Self-employed } & \multicolumn{2}{|c|}{ Paid employees } \\
\hline & univariate & multivariate & univariate & multivariate \\
\hline Female (dummy) & $-0.720^{* * *}(0.049)$ & $-0.332^{* * *}(0.049)$ & $-0.513^{* * *}(0.010)$ & $-0.126^{* * *}(0.008)$ \\
\hline \multicolumn{5}{|l|}{ Formal education (reference: no vocational degree) } \\
\hline No vocational degree \& FHR/Abitur (dummy) & & $-0.176(0.146)$ & & $-0.010(0.031)$ \\
\hline Vocational training (dummy) & & $0.029(0.121)$ & & $0.105^{* * *}(0.017)$ \\
\hline Vocational training \& FHR/Abitur (dummy) & & $0.068(0.131)$ & & $0.156^{* * *}(0.019)$ \\
\hline Vocational college ("Fachschule") (dummy) & & $0.043(0.127)$ & & $0.153^{* * * *}(0.020)$ \\
\hline University or university of applied science degree (dummy) & & $0.144(0.125)$ & & $0.284^{* * *}(0.019)$ \\
\hline Working experience (in years) & & $0.009(0.007)$ & & $0.024^{* * *}(0.001)$ \\
\hline Working experience squared & & $-0.0001(0.0001)$ & & $-0.0004^{* * *}(0.00003)$ \\
\hline Working intermissions (in years) & & $-0.029^{* *}(0.013)$ & & $-0.020^{* * *}(0.002)$ \\
\hline Working intermissions squared & & $0.0003(0.001)$ & & $0.001^{* * *}(0.0001)$ \\
\hline Tenure at current job (in years) & & $0.033^{* * *}(0.006)$ & & $0.018^{* * *}(0.001)$ \\
\hline Tenure at current job squared & & $-0.001^{* * *}(0.0002)$ & & $-0.0004^{* * *}(0.00004)$ \\
\hline Number of changes of profession & & $-0.031^{* * *}(0.010)$ & & $-0.011^{* * *}(0.002)$ \\
\hline Working hours per week (in logarithms) & & $0.665^{* * *}(0.053)$ & & $0.938^{* * *}(0.012)$ \\
\hline \multicolumn{5}{|l|}{ Working time flexibility (reference: never) } \\
\hline Sometimes (dummy) & & $0.052(0.074)$ & & $0.056^{* * *}(0.013)$ \\
\hline Often (dummy) & & $0.110(0.075)$ & & $0.076^{* * *}(0.013)$ \\
\hline \multicolumn{5}{|l|}{ Family background (reference: single and no young children) } \\
\hline Life partner (dummy) & & $0.001(0.041)$ & & $0.021^{* * *}(0.007)$ \\
\hline Young children (dummy) & & $-0.290(0.352)$ & & $0.048(0.030)$ \\
\hline Life partner and young children (interaction effect) & & $0.366(0.359)$ & & $-0.020(0.031)$ \\
\hline High career aspirations (dummy) & & $0.040(0.038)$ & & $-0.010(0.006)$ \\
\hline Professional field (54 dummies) & & Yes*** & & Yes $^{* * *}$ \\
\hline
\end{tabular}


Table 4 OLS monthly earnings regressions, men and women pooled ${ }^{\mathrm{a}}$ (Continued)

\begin{tabular}{lll}
\hline Tasks occurring at work (17 dummies) & Yes $^{* * *}$ \\
\hline Firm size (reference: 5-9 employees) & \\
\hline 1 employee (dummy) & $-0.087(0.058)$ \\
\hline 2 employees (dummy) & $-0.042(0.070)$ \\
\hline $3-4$ employees (dummy) & $0.0002(0.063)$ \\
\hline $10-19$ employees (dummy) & $0.081(0.080)$ \\
\hline $20-49$ employees (dummy) & $0.124(0.106)$ \\
\hline $50-99$ employees (dummy) & $0.132(0.191)$ \\
\hline 100 employees and more (dummy) & $-0.019(0.059)$ \\
\hline Constant & $0.124(0.170)$ \\
\hline Number of observations & $8.055^{* * *}(0.024)$ & $0.012(0.019)$ \\
\hline$R^{2}$ & 1,471 & $0.050^{* * *}(0.014)$ \\
\hline
\end{tabular}

${ }^{a}$ The data set used is the BIBB/BAuA Employment Survey 2006. Robust standard errors in brackets. ***/*** indicates statistical significance at the 10/5/1\% level. Additional control variables included are: migration background (1 dummy), disability status (3 dummies) and place of residence (16 "Bundesländer" dummies). "Abitur" is the German university entrance qualification, "FHR" ("Fachhochschulreife") the German university of applied science entrance qualification. Working time flexibility was measured by the frequency at which interviewees were able to take family and private interests into account when scheduling working time. The number of employees reported in the firm size variable includes the owner of the firm. 
Table 5 OLS monthly earnings regressions, men and women separately ${ }^{a}$

\begin{tabular}{|c|c|c|c|c|}
\hline \multirow{2}{*}{$\begin{array}{l}\text { dependent variable: logarithm of gross } \\
\text { monthly earnings }\end{array}$} & \multicolumn{2}{|c|}{ Self-employed } & \multicolumn{2}{|c|}{ Paid employees } \\
\hline & male & female & male & female \\
\hline \multicolumn{5}{|l|}{ Formal education (reference: no vocational degree) } \\
\hline No vocational degree \& FHR/Abitur (dummy) & $-0.163(0.178)$ & $-0.163(0.279)$ & $0.029(0.044)$ & $-0.083^{* *}(0.041)$ \\
\hline Vocational training (dummy) & $0.047(0.145)$ & $-0.022(0.209)$ & $0.166^{* * *}(0.023)$ & $0.049 * *(0.023)$ \\
\hline Vocational training \& FHR/Abitur (dummy) & $-0.061(0.156)$ & $0.143(0.231)$ & $0.201^{* * *}(0.028)$ & $0.111^{* * *}(0.026)$ \\
\hline Vocational college ("Fachschule") (dummy) & $-0.016(0.150)$ & $0.174(0.239)$ & $0.207^{* * *}(0.027)$ & $0.116^{* * *}(0.032)$ \\
\hline University or university of applied science (dummy) & $0.067(0.151)$ & $0.227(0.223)$ & $0.371^{* * *}(0.027)$ & $0.203^{* * *}(0.026)$ \\
\hline Working experience (in years) & $0.012(0.008)$ & $0.002(0.015)$ & $0.027^{* * *}(0.002)$ & $0.021^{* * *}(0.002)$ \\
\hline Working experience squared & $-0.0002(0.0001)$ & $0.0001(0.0003)$ & $-0.0004^{* * *}(0.00004)$ & $-0.0003^{* * *}(0.00004)$ \\
\hline Working intermissions (in years) & $-0.048^{* *}(0.020)$ & $-0.012(0.016)$ & $-0.023^{* * *}(0.004)$ & $-0.017^{* * *}(0.003)$ \\
\hline Working intermissions squared & $0.001(0.002)$ & $-0.0001(0.001)$ & $0.001^{* * *}(0.0002)$ & $0.0004^{* * *}(0.0001)$ \\
\hline Tenure at current job (in years) & $0.028^{* * *}(0.007)$ & $0.041^{* * *}(0.012)$ & $0.016^{* * *}(0.002)$ & $0.018^{* * *}(0.002)$ \\
\hline Tenure at current job squared & $-0.0005^{* *}(0.0002)$ & $-0.001 *(0.0004)$ & $-0.0004^{* * *}(0.0001)$ & $-0.0004^{* * *}(0.0001)$ \\
\hline Number of changes of profession & $-0.027^{* *}(0.010)$ & $-0.022(0.023)$ & $-0.009^{* * *}(0.003)$ & $-0.013^{* * *}(0.003)$ \\
\hline Working hours per week (in logarithms) & $0.501^{* * *}(0.068)$ & $0.777^{* * *}(0.090)$ & $0.840^{* * *}(0.027)$ & $0.949 * * *(0.015)$ \\
\hline \multicolumn{5}{|l|}{ Working time flexibility (reference: never) } \\
\hline Sometimes (dummy) & $-0.006(0.080)$ & $0.337^{* *}(0.159)$ & $0.042^{* *}(0.018)$ & $0.066^{* * *}(0.020)$ \\
\hline Often (dummy) & $0.013(0.082)$ & $0.414^{* * *}(0.157)$ & $0.069^{* * *}(0.018)$ & $0.074^{* * *}(0.020)$ \\
\hline \multicolumn{5}{|c|}{ Family background (reference: single and no young children) } \\
\hline Life partner (dummy) & $0.110^{* *}(0.050)$ & $-0.146^{*}(0.081)$ & $0.054^{* * *}(0.009)$ & $-0.004(0.009)$ \\
\hline Young children (dummy) & $0.770^{*}(0.462)$ & $-0.821 *(0.461)$ & $0.074(0.092)$ & $0.030(0.032)$ \\
\hline Life partner and young children (interaction effect) & $-0.702(0.468)$ & $0.943^{* *}(0.476)$ & $-0.034(0.092)$ & $-0.029(0.035)$ \\
\hline High career aspirations (dummy) & $0.043(0.042)$ & $0.018(0.080)$ & $-0.010(0.009)$ & $-0.014(0.009)$ \\
\hline Professional field (54 dummies) & Yes*** & Yes & Yes*** & Yes*** \\
\hline Tasks occurring at work (17 dummies) & Yes $^{* * *}$ & Yes $^{* * *}$ & Yes $^{* * *}$ & Yes $^{* * *}$ \\
\hline
\end{tabular}


Table 5 OLS monthly earnings regressions, men and women separately ${ }^{a}$ (Continued)

\begin{tabular}{|c|c|c|c|c|}
\hline \multicolumn{5}{|l|}{ firm size (reference: 5-9 employees) } \\
\hline 1 employee (dummy) & $-0.071(0.063)$ & $-0.091(0.143)$ & $0.136^{*}(0.075)$ & $-0.135^{*}(0.083)$ \\
\hline 2 employees (dummy) & $-0.094(0.075)$ & $0.027(0.161)$ & $-0.027(0.055)$ & $-0.087^{*}(0.050)$ \\
\hline 3-4 employees (dummy) & $-0.041(0.071)$ & $0.144(0.154)$ & $0.033(0.032)$ & $-0.028(0.023)$ \\
\hline 10-19 employees (dummy) & $0.071(0.089)$ & $0.046(0.175)$ & $0.053^{* *}(0.022)$ & $0.048^{* * *}(0.018)$ \\
\hline 20-49 employees (dummy) & $0.206^{*}(0.116)$ & $-0.061(0.234)$ & $0.107^{* * *}(0.021)$ & $0.081^{* * *}(0.017)$ \\
\hline 50-99 employees (dummy) & $0.139(0.201)$ & $-0.495 *(0.261)$ & $0.111^{* * *}(0.023)$ & $0.110^{* * *}(0.018)$ \\
\hline 100 employees and more (dummy) & $0.360^{*}(0.195)$ & $-0.259(0.279)$ & $0.212^{* * *}(0.020)$ & $0.190^{* * *}(0.016)$ \\
\hline Constant & $5.261^{* * *}(0.351)$ & $3.081^{* * *}(0.598)$ & $3.697^{* * *}(0.113)$ & $3.258^{* * *}(0.093)$ \\
\hline Number of observations & 974 & 497 & 7,094 & 6,887 \\
\hline$\overline{R^{2}}$ & 0.45 & 0.56 & 0.62 & 0.74 \\
\hline
\end{tabular}

${ }^{a}$ The data set used is the BIBB/BAuA Employment Survey 2006. Robust standard errors in brackets. ***/*** indicates statistical significance at the $10 / 5 / 1 \%$ level. Additional control variables included are: migration

background (1 dummy), disability status ( 3 dummies) and place of residence (16 "Bundesländer" dummies). "Abitur" is the German university entrance qualification, "FHR" ("Fachhochschulreife") the German university of applied science entrance qualification. Working time flexibility was measured by the frequency at which interviewees were able to take family and private interests into account when scheduling working time. The number of employees reported in the firm size variable includes the owner of the firm. 
is associated with $1.8 \log$ points additional income (average partial effect; significant at the 0.1 percent level). For women the respective average partial effect amounts to $2.9 \log$ points but this is not significantly different from men's. Tenure thus would be able to partly explain gender earnings differences in self-employment. A problem with interpreting this variable, however, might be that reverse causality cannot be excluded since businesses with low profits are likely to be closed first. Tenure is also relevant for paid employees' earnings, and again it does not affect men's and women's wages differently.

Finally we find that the number of changes of profession has an unexpected negative impact on self-employment earnings, which is insignificant for women. This is contrary to Lazear's (2004) jack-of-all-trades view of entrepreneurship but is consistent with the empirical evidence of Åstebro and Thompson (2011) who also find a negative effect of diverse experience on entrepreneurial income. This could be interpreted as an indication that individuals with a strong taste for variety are willing to give up income in order to gain variety (cf. Åstebro and Thompson 2011). Another possible explanation for this finding might be that individuals with lower productivity are less able to get a stable job.

\section{(2) Work family balance and working hours}

Working hours have been included in the regressions in logarithmic form, so that the respective coefficients can be interpreted as elasticities (although they should not be over-interpreted since earnings and the number of hours supplied are usually jointly determined). The results in Table 5 show that a one percent increase in working time is associated with an increase of 0.50 and 0.78 percent in self-employment earnings for men and women, respectively. The elasticity of men's earnings with respect to hours is also lower in salaried employment (the respective elasticities are 0.84 and 0.95 ). This is quite interesting given that men work so much more than women.

Regarding the balance of working time scheduling with family and private interests, more flexibility is associated with higher, not lower, earnings for self-employed women and paid employees (and does not seem to matter for self-employed men's earnings). Therefore one might reject the idea that women trade off earnings against working time flexibility.

That said, family background does seem to play a role for gender earnings differentials by affecting the earnings of self-employed men and women quite differently. Having a life partner and/or young children is negatively associated with self-employed women's earnings (as one would expect if family responsibilities held women back), but the respective coefficients are jointly statistically significant at the 10 percent level only. In contrast, the earnings of self-employed men are higher on average when living with a partner and/ or young children (jointly significant at the 5 percent level). By and large, a similar pattern shows up for paid employees although here the estimated coefficients are not statistically significant for women.

Finally, career aspirations have no statistically significant impact on male and female earnings in self-employment. For paid employees the respective coefficients even show an unexpected negative sign, but again they are not statistically significant ${ }^{11}$.

\section{(3) Segregation}

Concerning the variables capturing segregation, the dummies for the 54 professional fields are jointly statistically significant at the 0.1 percent level in all four earnings 
regressions and so are those for the tasks occurring at work. Firm size, however, only plays a role for paid employees' earnings, with wages being higher in large firms, whereas for the self-employed we find no clear relationship between firm size and earnings. We will analyze in section 4 to what extent these segregation variables contribute to explaining the gender earnings gap.

Taken together, the estimates presented in Table 5 indicate that the determinants of earnings differ substantially between self-employment and paid employment. Quite a few variables that are standard in earnings regressions for paid employees, such as formal education, general working experience and firm size, do not seem to affect earnings in self-employment. Correspondingly, it is much easier to explain the variance of wages in paid employment than that of earnings from self-employment. That said, the explanatory power of all four earnings regressions is highly satisfactory in terms of $R^{2}$, ranging from 45 percent (male self-employed) to 74 percent (female paid employees). Furthermore, with $\mathrm{R}^{2} \mathrm{~s}$ of 45 percent for men and 56 percent for women, the explanatory power of the self-employment estimations is still quite high given that some authors in the literature report relatively poor goodness-of-fit diagnostics for selfemployment earnings regressions ${ }^{12}$.

A potential problem with our estimations is that the coefficients of the earnings regressions might be biased because individuals did not randomly select into self- and paid employment. We tried to address this issue by correcting for selection into selfemployment, utilizing the Heckman (1979) approach and several exclusion restrictions like age, town size and existence of a working spouse. The coefficient of the inverse Mills-ratio (indicating selection) is negative and statistically significant at the 10 percent level for self-employed men, but insignificant (and positive) in the regression for women. Coefficients of explanatory variables barely change in both cases. However, the inverse Mills-ratios are highly correlated with the variables in the earnings regressions, so that their significance cannot be interpreted properly and subsample OLS may in fact be more robust (Puhani 2000). Unfortunately our data set does not provide us with better instruments to correct for selection, so that we decided to only present and make use of the estimations without selection correction (results of the selection correction regressions are available on request).

Note that our insights still hold when we perform a number of robustness checks. We restricted our sample to individuals aged 18 to 65 , thus excluding the small group of older persons in employment (among whom the self-employed play a more prominent role) and an even smaller group of persons aged 15 to 17 (who are mainly employees). We further re-ran our estimations using hourly earnings instead of monthly earnings as the dependent variable (and dropping working hours as an explanatory variable); the results of these estimations are shown in the Table 6. In order to check whether our estimated coefficients differ over the conditional earnings distribution, we also ran quantile regressions (at the 10th, 25th, 50th, 75th, and 90th percentiles). In the pooled self-employment earnings regression the sex dummy indicating the earnings gap decreases with the quantiles (i.e. it is highest at the 10 percent quantile) but it does not differ in a statistically significant way between the various quantiles. In the separate earnings regressions for male and female self-employed the coefficients of the explanatory variables also do not differ much over the conditional distribution of earnings. The 
results of these quantile regressions are not reported in tables but are available on request.

\section{Decomposition of the gender earnings gap}

While the analyses in sections 2 and 3 indicate which variables may be important in explaining the gender earnings gap, we now want to quantify the actual extent of gender earnings differences these variables account for. We utilize Oaxaca-Blinder decompositions (Oaxaca 1973, Blinder 1973; for a review of this method see Fortin et al. 2011) of self-employed's and paid employees' monthly earnings, alternatively with men and women as the reference group ${ }^{13}$. As self-employed women are not present in several professional fields where self-employed men are (and vice versa), we have to exclude these fields and observations from our analysis for the self-employed (whereas this is not the case for paid employees).

The results of these decompositions reported in Table 7 make clear that the share of the gender earnings gap which can be traced back to endowment differences is smaller in self-employment than in paid employment. If men (women) form the reference group, in self-employment 36 (37) log points out of a total gender earnings gap of 71 log points can be explained by different endowments, which is a share of 50 (52) percent. In paid employment about 71 (73) percent of the gender wage gap can be explained. This is not surprising, however, given that we are less successful in explaining the variance in self-employment earnings than the variance in wages (remember that the $R^{2}$ s are much lower in the self-employment earnings regressions than in the wage regressions for paid employment).

Looking at the relative contribution of our three categories of determinants discussed above, it is obvious that family-work balance and working hours contribute most to the explanation of the earnings differences between the sexes for both occupational groups ${ }^{14}$. For the self-employed endowment differences in these variables account for about 22 percent of the total gender earnings gap (which corresponds to 44 percent of the explained part of the gap) if men are the reference group, and these figures are even higher (although the coefficients do not differ in a statistically significant way) if we take women as the reference group. In the group of paid employees, family-work balance and working hours account for 49 (55) percent of the gender pay gap and for 70 (75) percent of the explained gap when men (women) are the reference group. A closer look shows, however, that the importance of this category is entirely due to differences in working hours, though working hours can explain less of the gender earnings difference in self-employment than they can in paid employment. In contrast, endowment differences in working time flexibility, family background and career aspirations only play a very minor role. While this seems to suggest that family considerations do not matter much for gender earnings differences in self-employment such a conclusion would neglect the finding above that family background affects the earnings of selfemployed men and women quite differently (which only shows up in the "unexplained part" of our decompositions).

Concerning the role of human capital, about 14 percent of the gender earnings gap in self-employment can be ascribed to differences in human capital endowments between the sexes (which is equivalent to more than a quarter of the explained gap). This is considerably more than the respective shares in paid employment. Finally, the 
Table 6 OLS hourly earnings regressions, men and women separately ${ }^{a}$

\begin{tabular}{|c|c|c|c|c|}
\hline \multirow{2}{*}{$\begin{array}{l}\text { dependent variable: logarithm of gross hourly } \\
\text { earnings }\end{array}$} & \multicolumn{2}{|c|}{ Self-employed } & \multicolumn{2}{|c|}{ Paid employees } \\
\hline & male & female & male & female \\
\hline \multicolumn{5}{|l|}{ Formal education (reference: no vocational degree) } \\
\hline No vocational degree \& FHR/Abitur (dummy) & $-0.075(0.184)$ & $-0.062(0.274)$ & $0.079 *(0.042)$ & $-0.068^{*}(0.040)$ \\
\hline Vocational training (dummy) & $0.043(0.154)$ & $-0.029(0.212)$ & $0.157^{* * *}(0.023)$ & $0.047^{* *}(0.023)$ \\
\hline Vocational training \& FHR/Abitur (dummy) & $-0.020(0.165)$ & $0.159(0.234)$ & $0.200^{* * *}(0.028)$ & $0.110^{* * *}(0.026)$ \\
\hline Vocational college ("Fachschule") (dummy) & $-0.011(0.159)$ & $0.202(0.251)$ & $0.198^{* * *}(0.027)$ & $0.115^{* * *}(0.032)$ \\
\hline University or university of applied science (dummy) & $0.065(0.161)$ & $0.254(0.227)$ & $0.360^{* * *}(0.027)$ & $0.201^{* * *}(0.026)$ \\
\hline Working experience (in years) & $0.004(0.007)$ & $-0.001(0.016)$ & $0.026^{* * *}(0.002)$ & $0.022^{* * *}(0.002)$ \\
\hline Working experience squared & $-0.00004(0.0001)$ & $0.0001(0.0003)$ & $-0.0004^{* * *}(0.00004)$ & $-0.0003^{* * *}(0.00004)$ \\
\hline Working intermissions (in years) & $-0.049^{* *}(0.021)$ & $-0.010(0.017)$ & $-0.021^{* * *}(0.004)$ & $-0.015^{* * *}(0.003)$ \\
\hline Working intermissions squared & $0.001(0.002)$ & $-0.00003(0.001)$ & $0.001^{* * *}(0.0002)$ & $0.0004^{* * *}(0.0001)$ \\
\hline Tenure at current job (in years) & $0.026^{* * *}(0.008)$ & $0.038^{* * *}(0.013)$ & $0.016^{* * *}(0.002)$ & $0.017^{* * *}(0.002)$ \\
\hline Tenure at current job squared & $-0.0005^{* *}(0.0002)$ & $-0.001(0.0004)$ & $-0.0004^{* * *}(0.0001)$ & $-0.0004^{* * *}(0.0001)$ \\
\hline Number of changes of profession & $-0.022^{*}(0.011)$ & $-0.017(0.023)$ & $-0.008^{* * *}(0.002)$ & $-0.014^{* * *}(0.003)$ \\
\hline \multicolumn{5}{|l|}{ working time flexibility (reference: never) } \\
\hline Sometimes (dummy) & $0.057(0.084)$ & $0.327^{* *}(0.159)$ & $0.053^{* * *}(0.018)$ & $0.071^{* * *}(0.020)$ \\
\hline Often (dummy) & $0.199 * *(0.085)$ & $0.459^{* * *}(0.152)$ & $0.094^{* * *}(0.018)$ & $0.086^{* * *}(0.020)$ \\
\hline \multicolumn{5}{|c|}{ Family background (reference: single and no young children) } \\
\hline Life partner (dummy) & $0.119^{* *}(0.052)$ & $-0.119(0.080)$ & $0.051^{* * *}(0.009)$ & $0.002(0.009)$ \\
\hline Young children (dummy) & $0.717(0.502)$ & $-0.765^{*}(0.448)$ & $0.071(0.092)$ & $0.042(0.032)$ \\
\hline Life partner and young children (interaction effect) & $-0.662(0.507)$ & $0.932^{* *}(0.464)$ & $-0.031(0.093)$ & $-0.031(0.036)$ \\
\hline High career aspirations (dummy) & $0.024(0.044)$ & $0.012(0.080)$ & $-0.012(0.009)$ & $-0.017^{*}(0.009)$ \\
\hline Professional field (54 dummies) & Yes*** & Yes*** & Yes*** & Yes $* * *$ \\
\hline Tasks occurring at work (17 dummies) & Yes ${ }^{* * *}$ & Yes**** & Yes $* * *$ & Yes $* * * *$ \\
\hline
\end{tabular}


Table 6 OLS hourly earnings regressions, men and women separately ${ }^{\mathrm{a}}$ (Continued)

\begin{tabular}{|c|c|c|c|c|}
\hline Firm size (reference: 5-9 employees) & & & & \\
\hline 1 employee (dummy) & $-0.014(0.067)$ & $-0.093(0.147)$ & $0.133^{*}(0.076)$ & $-0.129(0.081)$ \\
\hline 2 employees (dummy) & $-0.076(0.079)$ & $0.017(0.166)$ & $-0.023(0.054)$ & $-0.084^{*}(0.050)$ \\
\hline 3-4 employees (dummy) & $-0.055(0.076)$ & $0.134(0.159)$ & $0.027(0.032)$ & $-0.027(0.023)$ \\
\hline 10-19 employees (dummy) & $0.079(0.089)$ & $0.042(0.181)$ & $0.051^{* *}(0.022)$ & $0.045^{* *}(0.018)$ \\
\hline 20-49 employees (dummy) & $0.236^{* *}(0.113)$ & $-0.043(0.234)$ & $0.102^{* * *}(0.021)$ & $0.076^{* * *}(0.017)$ \\
\hline 50-99 employees (dummy) & $0.157(0.222)$ & $-0.471^{*}(0.262)$ & $0.104^{* * *}(0.022)$ & $0.104^{* * *}(0.018)$ \\
\hline 100 employees and more (dummy) & $0.405^{*}(0.213)$ & $-0.184(0.281)$ & $0.207^{* * *}(0.020)$ & $0.183^{* * *}(0.016)$ \\
\hline Constant & $1.921^{* * *}(0.284)$ & $0.863(0.536)$ & $1.673^{* * *}(0.059)$ & $1.620^{* * *}(0.076)$ \\
\hline Number of observations & 974 & 497 & 7,094 & 6,887 \\
\hline$\overline{R^{2}}$ & 0.38 & 0.41 & 0.48 & 0.47 \\
\hline
\end{tabular}


Table 7 Oaxaca-Blinder decompositions of the gender earnings gap for self-employed and paid employees (characteristics effects) ${ }^{a}$

\begin{tabular}{|c|c|c|c|c|c|c|}
\hline \multirow{2}{*}{$\begin{array}{l}\text { dependent variable: } \\
\text { logarithm of gross } \\
\text { monthly earnings }\end{array}$} & \multicolumn{3}{|c|}{ Self-employed $(N=1,387)$} & \multicolumn{3}{|c|}{ Paid employees $(\mathrm{N}=13,981)$} \\
\hline & log points & $\begin{array}{l}\text { share of total gap } \\
\text { (in percent) }\end{array}$ & $\begin{array}{l}\text { share of explained gap } \\
\text { (in percent) }\end{array}$ & log points & $\begin{array}{l}\text { share of total gap } \\
\text { (in percent) }\end{array}$ & $\begin{array}{c}\text { share of explained gap } \\
\text { (in percent) }\end{array}$ \\
\hline \multicolumn{7}{|l|}{ Reference group: men } \\
\hline Gender earnings gap & $0.71^{* * *}(0.05)$ & & & $0.51 * * *(0.01)$ & & \\
\hline Explained & $0.36^{* * *}(0.05)$ & 50.0 & & $0.36^{* * *}(0.01)$ & 70.7 & \\
\hline Human capital & $0.10^{* * *}(0.03)$ & 14.6 & 29.3 & $0.03^{* * *}(0.005)$ & 6.5 & 9.1 \\
\hline Family-work balance \& hours & $0.16^{* * *}(0.03)$ & 22.1 & 44.3 & $0.25^{* * *}(0.01)$ & 49.3 & 69.7 \\
\hline \multicolumn{7}{|l|}{ Thereof: } \\
\hline Working hours & $0.17^{* *}(0.03)$ & 23.1 & 46.3 & $0.25^{* * *}(0.01)$ & 49.4 & 69.8 \\
\hline Segregation & $0.09^{* * *}(0.03)$ & 12.7 & 25.5 & $0.07^{* * *}(0.01)$ & 14.3 & 20.2 \\
\hline Control variables & $0.004(0.01)$ & 0.5 & 1.0 & $0.003^{*}(0.002)$ & 0.7 & 0.9 \\
\hline \multicolumn{7}{|l|}{ Reference group: women } \\
\hline Gender earnings gap & $0.71^{* * *}(0.05)$ & & & $0.51 * * *(0.01)$ & & \\
\hline Explained & $0.37^{* * *}(0.06)$ & 52.3 & & $0.37^{* * *}(0.01)$ & 73.0 & \\
\hline Human capital & $0.10^{* * *}(0.03)$ & 14.2 & 27.1 & $0.03^{* * *}(0.004)$ & 5.5 & 7.5 \\
\hline Family-work balance \& hours & $0.23^{* * *}(0.04)$ & 31.7 & 60.7 & $0.28^{* * *}(0.01)$ & 54.9 & 75.3 \\
\hline \multicolumn{7}{|l|}{ Thereof: } \\
\hline Working hours & $0.25^{* * *}(0.04)$ & 34.8 & 66.7 & $0.29^{* * *}(0.01)$ & 55.8 & 76.4 \\
\hline Segregation & $0.04(0.05)$ & 6.0 & 11.5 & $0.06^{* * *}(0.01)$ & 12.0 & 16.5 \\
\hline Control variables & $0.003(0.01)$ & 0.4 & 0.7 & $0.003^{*}(0.001)$ & 0.5 & 0.7 \\
\hline
\end{tabular}

${ }^{a}$ The data set used is the BIBB/BAuA Employment Survey 2006. Robust standard errors in brackets. */***** indicates statistical significance at the $10 / 5 / 1 \%$ level. Control variables are: migration background, disability status, place of residence. 
share of gender earnings differences in self-employment that can be explained by segregation depends on whether we use men or women as the reference group. If women were remunerated in the same way as men, working in the same professional fields, performing the same tasks and running firms of the same size would reduce the gender earnings gap by almost 13 percent. However, when taking the opposite perspective (i.e. using women as the reference group), segregation plays a statistically insignificant role. In both cases, segregation seems to be of less importance for earnings differences in self-employment than in paid employment.

Our conclusions did not change when we performed several robustness checks to assess the sensitivity of these results. First of all, we were concerned about the interrelationship between working hours and family considerations. Women may choose to work fewer hours precisely for the reason of family considerations. Thus one reason for the missing contribution of family background, working time flexibility and career aspiration to the gender earnings gap may be that the effects of these variables are already picked up by working hours. In order to check the degree of collinearity between those variables, we ran a regression of log working hours on working time flexibility, family background (i.e. the dummies indicating a life partner, young children, and their interaction effect), and career aspiration. It turned out that only 17 (13) percent of the variance of the working hours of male (female) self-employed individuals can be explained by family background, flexibility and career aspirations. Thus multicollinearity is arguably not a problem here. Additionally we re-ran the Oaxaca-Blinder decompositions excluding working hours from the model, but the contribution of the work-family balance variables to explaining the gender earnings gap remained very limited and was not statistically significantly different from zero at conventional levels. As a further robustness check, we differentiated between couples where both spouses were employed and those where only one of them was employed (namely, the interviewee) ${ }^{15}$. Still family background together with flexibility and career aspirations did not contribute to explaining the gender earnings gap in self-employment, regardless of whether we used men or women as the reference group or included or excluded working hours in the model. The respective estimations are not reported in tables but are available on request.

Given the rich information provided in our data set, we also tried to capture segregation in some other ways. For instance, we replaced the professional fields by a large array of job characteristics such as basic and expert skill requirements in certain areas and physical and mental strains at the workplace (inter alia: exposure to noise, dirt, coldness, hazardous substances etc. or strong pressure on time and performance). Still segregation did not explain a larger proportion of the earnings gap.

\section{Conclusions}

Utilizing a large and representative data set, this study has attempted to provide an explanation for the gender gap in self-employment earnings in Germany using the gender pay gap in paid employment as a benchmark. We find that the raw earnings differential between men and women amounts to 44 percent in self-employment whereas it is only 36 percent in paid employment. The gender gap is not only larger in self-employment, but also the part of it that cannot be explained by differences in the characteristics of men and women is larger in self-employment than in paid employment. 
The largest contribution to explaining the gender earnings gap in self-employment is made by differences in working hours. About one quarter to one third of the difference in monthly earnings can be traced back to women working fewer hours than men. In contrast to working hours, variables like working time flexibility and career aspirations do not seem to contribute substantially to the gender earnings gap (at least not beyond their limited effect on working hours visible in our data) ${ }^{16}$. Family background also does not play a significant role in the explained part of our Oaxaca-Blinder decompositions but it is relevant for the gender earnings gap by affecting the earnings of selfemployed men and women quite differently.

Our finding that both the raw and the unexplained gender earnings gap are higher in self-employment than in paid employment (which confirms some previous studies for other countries) is somewhat puzzling given that, in contrast to paid employment, there can be no employer discrimination in self-employment. While a possible explanation could be that discrimination by customers, suppliers or capital providers plays a role, there is little empirical support for this from other studies. Nevertheless, in future research it would certainly be sensible to take financial (start-up) capital into account where possible (as has already been done in previous studies for other countries, e.g. by Hundley 2001, Walker 2009 and Rybczynski 2009). Other variables that could help explaining the remaining part of the gender earnings gap might be personality traits like attitude towards risk or competitiveness (for paid employees this has been explored e.g. by Semykina and Linz 2007). A limitation of our data (and of many other data sets) is that such information is not available ${ }^{17}$ and that our data is only cross-sectional. Finally, obtaining suitable data and finding convincing instruments for selection correction would be helpful in future research to improve the reliability of our results.

Despite these caveats, however, our empirical analysis has been able to show that the determinants of earnings as well as the gender earnings gaps differ substantially between self-employment and paid employment. Our finding that both the raw and the unexplained gender earnings gap are higher in self-employment than in paid employment has two unpleasant political implications. First, promoting female self-employment seems to be no panacea for reducing earnings inequality between men and women. Second, as we know less about the causes of the earnings differential in self-employment, politicians eager to overcome this inequality find even fewer political starting-points here. It clearly needs further research before we are able to give policy advice whether and how to address the gender earnings gap in self-employment.

\section{Endnotes}

${ }^{1}$ In addition, quite a few studies relate the gender composition of the management to various indicators of firm performance (i.e. survival, employment growth, sales growth, etc.), see, inter alia, Gottschalk and Niefert (2011), Fairlie and Robb (2009), Du Rietz and Henrekson (2000), Fischer et al. (1993).

${ }^{2}$ Excluding these extreme values considerably improves the statistical fit of our estimations, without substantially altering our main insights.

${ }^{3}$ Based on GSOEP data for 2007, Gather et al. (2010), report gender earnings differences of similar magnitude: Among fulltime self-employed workers they calculate a gender earnings gap of 34.7 percent, among fulltime paid employees a gender wage gap of 22.6 percent. 
${ }^{4}$ A fourth category that has been investigated in the literature is financial capital (see, e.g., Hundley 2001, Walker 2009) but unfortunately our data set does not contain information on this variable.

${ }^{5}$ Of course, even if there were no endowment differences within the occupational groups, it could still be different impacts of endowments that made the difference; this issue will be explored in sections 3 and 4 .

${ }^{6}$ One study questioning this idea is Konietzko (2012), who does not find a negative effect of housework on the earnings of the self-employed in Germany.

${ }^{7}$ This does not necessarily mean that women's work is not as complex as men's since other classifications of tasks might well produce other results.

${ }^{8}$ For small numbers log points are approximately equal to percentage points. For larger numbers as here, one can calculate the approximate corresponding percentage points by the formula $e^{\beta}-1$, where $\beta$ is the estimated coefficient.

${ }^{9}$ Since intermissions have been included in a non-linear manner the respective numbers relate to the average partial effects.

${ }^{10} \mathrm{Cf}$. Williams (2000) who shows that working experience in self-employment affects negatively the returns to working experience when returning to paid employment, at least for women.

${ }^{11}$ It could be argued that career aspirations might be endogenous if individuals adjust their aspirations downwards in response to facing (unexpectedly) low earnings. In this case the respective coefficients may be upward biased, but this would not change our conclusion that career aspirations play a minor role for gender earnings differences.

12 Åstebro (2012: 90) for instance, states that "[p]redictors of entrepreneurial earnings are typically weak, and the total explained variance, if one throws in everything and the kitchen sink (except fixed effects), is typically less than 10 percent." See also Parker (2009: 380) for a similar statement.

${ }^{13}$ Decomposing hourly earnings instead of monthly earnings did not yield any additional insights.

${ }^{14}$ This contribution refers to the so-called "explained part" of the gender earnings gap, i.e. the part that can be explained by endowment differences between the sexes. If it is differences in the effects of variables that contribute to the gender earnings differential, this does not show up in the "explained part" of an Oaxaca-Blinder decomposition but is included in the "unexplained part".

15 The "life partner" dummy was split into two dummies, one dummy indicating a non-employed partner and the other dummy indicating an employed partner. Both dummies were interacted with "young children". Due to the potential endogeneity of the employment status of the partner (e.g. "added worker effect") we decided not to present this specification as our main model.

${ }^{16}$ Note that the results of previous studies that include similar explanatory variables are not that clear. In Hundley (2001) housework hours explain between 2.7 and 25.5 percent of the earnings gap, depending on whether monthly or hourly earnings are considered and whether men or women are chosen as the reference group. In the analysis of Walker (2009), also with a U.S. dataset (that however only provides categorical earnings information), the contributions of work hours, housework hours, housework effort and flexible work hours all depend heavily on the reference group as well. 
17 This deficit is also lamented by Caliendo and Kritikos (2012: 323) "In an ideal world researchers would have access to data that includes personality characteristics and psychological traits, motivational factors and cognitive skills. In this respect the research community needs to find new ways to collect these data and make them available for entrepreneurship research."

\section{Competing interests}

The "IZA Journal of European Labor Studies" is committed to the IZA Guiding Principles of Research Integrity. The authors declare that they have observed these principles.

\section{Acknowledgements}

For helpful comments and suggestions we would like to thank an anonymous referee of this journal as well as Boris Hirsch, Monika Jungbauer-Gans, Thorsten Konietzko, Michael Oberfichtner, Joachim Wagner and participants in the 1st Potsdam PhD Workshop in Empirical Economics, 2012.

Responsible editor: Alan Barrett

Received: 19 September 2012 Accepted: 18 December 2012

Published: 28 December 2012

\section{References}

Altonji JG, Blank RM (1999) Race and gender in the labor market. In: Card D, Ashenfelter OC (eds) Handbook of labor economics, vol 3C. North-Holland, Amsterdam, pp 3143-3259

Álvarez G, Gradín C, Otero MS (2009) Self-employment in Spain: transition and earnings differential. Universidade de Vigo, Departamento Economía Aplicada Documento de Traballo 0907, Vigo

Aronson RL (1991) Self-employment. A labor market perspective. ILR Press, Ithaca, NY

Asiedu E, Freeman JA, Nti-Addae A (2012) Access to credit by small businesses: How relevant are race, ethnicity, and gender? Am Econ Rev 102:532-537

Åstebro T (2012) The returns to entrepreneurship. In: Cumming D (ed) The Oxford handbook of entrepreneurial finance. Oxford University Press, New York

Åstebro T, Thompson P (2011) Entrepreneurs, jacks of all trades or hobos? Res Policy 40:637-649

Becker GS (1985) Human capital, effort, and the sexual division of labor. J Labor Econ 3:33-58

Blinder AS (1973) Wage discrimination: Reduced form and structural estimates. J Hum Resour 8:436-455

Boden RJ (1999) Flexible working hours, family responsibilities, and female self-employment. Am J Econ Sociol 58:71-83

Caliendo M, Kritikos AS (2012) Searching for the entrepreneurial personality: New evidence and avenues for further research. J Econ Psychol 33:319-324

Coleman S (2000) Access to capital and terms of credit: A comparison of men- and women-owned small businesses. J Small Bus Manage 38:37-52

Du Rietz A, Henrekson M (2000) Testing the female underperformance hypothesis. Small Bus Econ 14:1-10

Eastough K, Miller PW (2004) The gender wage gap in paid- and self-employment in Australia. Aust Econ Pap 43:257-276

European Commission (2011) Report on progress on equality between women and men in 2010, The gender balance in business leadership. Publications Office of the European Union, Luxembourg. doi:10.2767/99441

Fabowale L, Orser B, Riding A (1995) Gender, structural factors, and credit terms between Canadian small businesses and financial institutions. Entrep Theory Pract 19:41-65

Fairlie RW, Robb AM (2009) Gender differences in business performance: Evidence from the characteristics of business owners survey. Small Bus Econ 33:375-395

Fischer EM, Reuber AR, Dyke LS (1993) A theoretical overview and extension of research on sex, gender, and entrepreneurship. J Bus Venturing 8:151-168

Fortin N, Lemieux T, Firpo S (2011) Decomposition methods in economics. In: Ashenfelter OC, Card D (eds) Handbook of labor economics, vol 4A. North-Holland, Amsterdam, pp 1-102

Gather C, Schmidt T, Ulbricht S (2010) Der Gender Income Gap bei den Selbstständigen - Empirische Befunde. In: Bührmann AD, Pongratz HJ (eds) Prekäres unternehmertum. Unsicherheiten von selbstständiger Erwerbstätigkeit und Unternehmensgründung, VS Verlag für Sozialwissenschaften, Wiesbaden

Gerlach I, Damhus C (2010) Berufliche Selbständigkeit als Strategie zur Vereinbarkeit von Beruf und Familie? Übersicht zum Stand der Forschung. Forschungszentrum Familienbewusste Personalpolitik Arbeitspapier 6, Berlin, Münster

Gottschalk S, Niefert M (2011) Gender differences in business success of German start-up firms. ZEW Discussion Paper 11-019, Mannheim

Hall A, Tiemann M (2006) BIBB/BAuA employment survey of the working population on qualification and working conditions in Germany 2006, suf_1.0. Research data center at BIBB (ed), GESIS cologne, Germany (data access). Federal Institute of Vocational Education and Training, Bonn. doi:10.4232/1.4820

Heckman JJ (1979) Sample selection bias as a specification error. Econometrica 47:153-161

Hundley G (2000) Male/female earnings differences in self-Employment: The effects of marriage, children, and the household division of labor. Ind Labor Relat Rev 54:95-114

Hundley G (2001) Why women earn less than men in self-employment. J Labor Res 22:817-829

Jungbauer-Gans M (1999) Der Lohnunterschied zwischen Frauen und Männern in selbständiger und abhängiger Beschäftigung. Koln Z Soziol Sozialpsych 51:364-390

Konietzko T (2012) Self-employed individuals, time use, and earnings. Friedrich-Alexander-University ErlangenNuremberg, Chair of Labour and Regional Economics Discussion Paper 78, Nuremberg 
Lauxen-Ulbrich M, Leicht R (2005) Wie Frauen gründen und was sie unternehmen: Nationaler Report Deutschland. Statistiken über Gründerinnen und selbständige Frauen. Institut für Mittelstandsforschung, University of Mannheim, Mannheim, Teilprojekt

Lazear EP (2004) Balanced skills and entrepreneurship. Am Econ Rev 94:208-211

Leung D (2006) The male/female earnings gap and female self-employment. J Socio-Econ 35:759-779

Lombard KV (2001) Female self-employment and demand for flexible, nonstandard work schedules. Econ Inq 39:214-237

Minniti M (2009) Gender issues in entrepreneurship. Found Trends Entrep 5:497-621

Moore RL (1983) Employer discrimination: Evidence from self-employed workers. Rev Econ Stat 65:496-501

Oaxaca R (1973) Male-female wage differentials in urban labor markets. Int Econ Rev 14:693-709

Orser BJ, Riding AL, Manley K (2006) Women entrepreneurs and financial capital. Entrep Theory Pract 30:643-665

Parker SC (2009) The economics of entrepreneurship. Cambridge University Press, Cambridge, UK; New York

Puhani P (2000) The Heckman correction for sample selection and its critique. J Econ Surv 14:53-68

Rybczynski K (2009) Are liquidity constraints holding women back? An analysis of gender in self-employment earnings. J Econ Asymmetries 6:141-165

Semykina A, Linz SJ (2007) Gender differences in personality and earnings: Evidence from Russia. J Econ Psychol 28:387-410

Tansel A (2000) Wage earners, self-employed and gender in the informal sector in Turkey. doi:10.2139/ssrn.263275, Available via SSRN. http://ssrn.com/abstract=263275. Accessed 19 September 2012

Tiemann M, Schade H-J, Helmrich R, Hall A, Braun U, Bott P (2008) Berufsfeld-Definitionen des BIBB auf Basis der Klassifikation der Berufe 1992. Wissenschaftliche Diskussionspapiere des BIBB 105, Bonn

Verheul I, Thurik R (2001) Start-up capital: "Does gender matter?". Small Bus Econ 16:329-346

Walker JR (2009) Earnings, effort, and work flexibility of self-employed women and men: the case of St. Croix county, Wisconsin. J Labor Res 30:269-288

Weichselbaumer D, Winter-Ebmer R (2005) A meta-analysis of the international gender wage gap. J Econ Surv 19:479-511

Williams DR (2000) Consequences of self-employment for women and men in the United States. Labour Econ 7:665-687

Williams DR (2003) Returns to education and experience in self-employment: evidence from Germany. Schmollers Jahrb 123:139-150

Zopf S, Tiemann M (2010) BIBB/BAuA-employment survey 2005/06. Schmollers Jahrb 130:409-420

doi:10.1186/2193-9012-1-6

Cite this article as: Lechmann and Schnabel: Why is there a gender earnings gap in self-employment? A

decomposition analysis with German data. IZA Journal of European Labor Studies 2012 1:6.

\section{Submit your manuscript to a SpringerOpen ${ }^{\circ}$} journal and benefit from:

- Convenient online submission

- Rigorous peer review

- Immediate publication on acceptance

- Open access: articles freely available online

- High visibility within the field

- Retaining the copyright to your article

Submit your next manuscript at $>$ springeropen.com 